\title{
Farmers Promoting information organisations and quality chains in Vietnam \\ and cooperation
}

\author{
Paule Moustier, Dao The Anh
}

all countries, demand for quality food is on the increase. Governments and multinationals are promulgating rules and standards regarding production conditions, inspections and certification. But smallholders often struggle to meet such conditions and to take advantage of these new opportunities.

Vietnam provides a good example of this issue. Demand for safe and tasty food is rapidly increasing in domestic and international markets. Family farmers cultivating small areas - the vast majority of producers - cannot meet this demand adequately, despite active public policies in favour of quality. What can be done to remedy this situation?

\section{Public policies focusing on regulations}

For the last 20 years, and especially since 2003 (with the ordinance on food safety), the Vietnamese government has been pursuing an active food safety policy, promulgating laws, organising training courses and supporting supermarkets. It has a dual objective: protecting consumer health and improving the competitiveness of agricultural products on the national market and for export.

perspoctive

Through Perspective CIRAD provides the opportunity to explore new avenues for discussion and action based on research, without presenting an institutional position
The government is at its most enterprising when it comes to regulations - over 300 laws drafted by different ministries have been published, laying down compulsory standards or certification processes. Difficulties in implementing or monitoring these standards have led it to maintain a certain degree of pragmatism, as shown by the approach adopted for vegetables.

In 1989 , a compulsory standard on the nontoxicity of food was drawn up based on the Codex Alimentarius. Enforcement was weak, as producers received insufficient information and few inspections were carried out due to the lack of infrastructure. The authorities thus decided to supplement the standard with certification concerning food production conditions, especially in terms of the environment. A "safe vegetables" certification process was set up in 1996, and later updated.

The VietGAP (good agricultural practices) standard was implemented in 2008. It is based on the ASEANGAP HACCP (Hazard Analysis Critical Control Point) principles. It requires producers to record their practices and to inspect production and 
Few small-scale producers succeed in obtaining "safe vegetables" certification.

\section{TO FIND OUT MORE}

Codron J.-M., Fares M., Rouvière É., 2007. From public to private safety regulation? The case of negotiated agreements in the French fresh produce import industry. International Journal of Agricultural Resources, Governance and Ecology, 6(3): 415-427.

Dao Duc Huan, 2009. Management policy on food hygiene and safety, current issues and challenges. Paper presented at Malica workshop "Food safety and innovations in supply chains", December 15, Hanoi, Malica, Ipsard/ Rudec.

Khosla R., 2006. A participatory organic guarantee system for India. Final report, 53 p., http:// www.ifoam.org

Kaganzi E., Ferris S., Barham J., Abenakyo A., Sanginga P. \& Njuki J.,2008. Sustaining linkages to high-value markets through collective action in Uganda. Food Policy, 34(1): 23-30.

Vietnam Ministry of Agriculture, Ministry of Health, Cida. 2009. Report on Supplementary Food Safety Survey Results. post-harvest activities (internal inspections) according to several food safety criteria (the pesticides used, the time between treatment and harvesting, the organisation of traceability, etc.). An external auditor checks these internal records using the producers' registers and information from the field. The government aims to ensure that VietGAP is respected in half of all vegetable- and tea-producing areas by 2015 .

To date, the results are modest. Less than $5 \%$ of vegetables are identified as safe by consumers in Hanoi. Tests on 144 samples of vegetables revealed that $12 \%$ exceeded the authorised limits for pesticide residues. Few small-scale producers succeed in obtaining "safe vegetables" certification and struggle even more to meet VietGAP standards, which are more recent.

Technical documents transcribing the standards are lacking, but these poor results are primarily explained by insufficient control. First, the internal inspections required by VietGAP assume that producers have the human and financial means to monitor their production and to ensure the specifications are met. Furthermore, the cost of external inspections is high -1000 euros for one hectare with VietGAP. This is out of reach for small-scale producers; only groups of producers and agricultural enterprises can afford this. Finally, governmental difficulties persist: in ensuring compliance with the rules, which is made all the more difficult by the fact that the production units are small; in specifying whether the standards are compulsory or voluntary; and in applying penalties.

The Vietnamese government also intervenes to promote quality linked to the origin of products. It has recognised 15 geographical indications (GIs), mainly for tea, coffee, rice, fruit and fish sauce. It sets the conditions for registering these GIs: defining the area in which they must be produced and the need to establish a link between this area and a characteristic of the product, or its reputation. But again, control is insufficient in this field. There are numerous cases of fraud; traders can sell any products as coming from a renowned area. Products are rarely labelled and the places selling such products are poorly identified, making things even more difficult for consumers. Furthermore, there are no plans for communication, such as logos or public or collective advertising.

Another element of government action is the organisation of training courses on agricultural practices to meet standards. Here again, success is only limited. Producers struggle to understand and apply the practices proposed. Furthermore, the training courses focus on technical aspects; they pay insufficient attention to inspections and overlook marketing and the organisation of producers.

This leaves supermarkets. Considering that mass retailing is a vehicle for modernisation and a guarantee of food safety, the authorities provide it with support. Either directly, by reserving areas in towns for supermarkets in a context of high pressure for land, and by appealing to investors for the establishment of supermarkets. Or indirectly, by demolishing numerous local markets, which are then replaced by shopping centres, and by declaring street selling illegal in most of the busy streets in towns. However, in Vietnam, supermarkets tend to exclude the poor, whether consumers, producers or distributors. The prices and the geographical distance exclude the poorer consumers. Demands for regular, diversified supplies and for quality certification and registration all eliminate small-scale producers and distributors from this kind of distribution, if they sell in an individual manner.

\section{Providing support to producers}

How then can government action be supplemented so as to facilitate access for small-scale producers to outlets that have quality requirements? The pilot initiatives conducted within the framework of the Superchain project provide some answers and food for thought. Based on information and cooperation within networks, they consist in studies, training courses and meetings.

Three chains (sticky rice, mountain beef, and vegetables) were chosen because they involve poor producers, they are linked to the Hanoi market and they promote a specific quality. 

up the advantages of joining forces.
The producers weighed

Consumer and retailer demand for quality food was first identified. Demand differs according to the chain. For sticky rice, consumers are concerned by aroma and cooking quality. For beef, in addition to taste, concerns focus on the health and the natural diet of the animal. For vegetables, the most restrictive requirement is set by supermarkets: a food safety certificate and a diversified supply of more than 10 products). Consumers and retailers share a lack of knowledge as to the origin of products and the characteristics of the area in which they are produced.

The findings were discussed during consultations between a panel of producers, traders and representatives of consumers and the authorities. The producers weighed up the advantages of joining forces to implement internal inspections, to reduce the unit costs of external inspections and to develop communication strategies with distributors and consumers allowing higher prices.

Seven farmers organisations (FOs) were created for vegetables (143 producers over 6 hectares); three for sticky rice (134 producers over 6 hectares); and two for beef (50 producers and 148 head of cattle).

Protocols were drawn up with producers in order to comply with the regulations (and, for vegetables, with the VietGAP standards) and to meet consumer expectations. They set out precise specifications on the



use of chemicals, types of seeds or animal breeds, fertilisation methods, animal feed and the treatment of disease, etc.

The aromatic sticky rice chain provides an interesting example. Internal quality inspections (meeting the specifications) are done by officials within each group. External inspections (rice cleanliness) are carried out by the health department of the province. A logo and packaging were created; they are recognised and appreciated by distributors and consumers. The association has signed contracts with two distribution companies, four shops and one supermarket. The producers' incomes have increased by $40 \%$.

For supermarkets, once quality was guaranteed, the project tackled the issue of the lack of supply diversity. An "alliance" of 33 producers groups and distribution companies for certified "safe" vegetables was set up in the Hanoi province. Their representatives meet regularly to coordinate their supply. A list of safe vegetable producers groups has been established, as well as a web site. For each chain, more direct relations were established between producers and distributors, or even consumers (see diagram).

\section{Associating public and private regulation}

Lessons learnt from these pilot initiatives could be used to inspire other projects in Vietnam and elsewhere.

First, associating public and private regulation provides satisfactory results. Public health standards are supplemented by the standards that producers voluntarily adopt and transcribe into specifications. Monitoring is carried out by inspectors who are members of the farmers organisations (internal monitoring) and by public inspectors (external monitoring). Likewise, sanctions (the threat of withdrawing certification) may be imposed by either the association or the public authorities. The findings of inspections are discussed within the FOs, and training courses are organised by the government in order to align practices.

Special attention should be given to the size of farmers organisations. If they are too big, 
Local direct sales

in shops run

by producers

foster information sharing and trust.

Editor:

Patrick Caron,

Director of Research and Strategy

Coordination:

Corinne Cohen, Department for Scientific and Technical Information

Graphic design:

Patricia Doucet , Communication office

\section{Layout:}

Laurence Laffont quality control is not strict enough; if they are too small, supermarket supply is suboptimal in terms of quality and quantity.

Furthermore, it would be interesting to develop outlets that do not require formal quality certification, which is costly for farmers organisations. Local direct sales in shops run by producers, or on local markets, foster information sharing and trust. They allow producers to achieve greater profit margins as well as enabling poor consumers to buy quality products.

Some interesting Participatory Guarantee Systems (PGS) are being tested by private operators in organic farming projects. They involve actors in the chain, especially producers and consumers. A local group, including producers, traders and members of NGOs and of consumer organisations, inspects farmers (based on field observations and documentation) and produce a report. Based on this report, a coordination group, with representatives of the profession, consumers and experts, grants PGS certification.

Finally, promoting quality procedures among small-scale producers implies the existence of mediators who take charge of the coordination work, which is carried out here by the Superchain project.
All that remains is to measure the impact of the process on producers' income, along with the cost of extending it on a large scale. And finally, exploring whether the chains that develop quality labels can lead the way for conventional chains that have no label, or whether they generate new forms of exclusion.

\section{A few words about...}

Paule Moustier

An economist at CIRAD in the MOISA - Markets, Organisations, Institutions and Stakeholder Strategies mixed research unit (http://umr-moisa.cirad.fr/), Paule Moustier works on the organisation and performance of food chains supplying towns in Africa and Asia. From 2002

to 2009, she was based in Hanoi within the MALICA research consortium. From 2007 to 2009, she coordinated the Superchain project.

paule.moustier@cirad.fr

Dao The Anh

Director of the Center for Agrarian Systems Research and Development (CASRAD) at the Vietnam Academy of Agricultural Science (http://www.casrad.org.vn ), Dao The

Anh is an agricultural economist. He has coordinated numerous projects on food chains, farmers organisations and quality management in Vietnam.

daotheanh@gmail.com
This issue of Perspective presents the findings of two projects:

- The Superchain development research project in Vietnam on small-scale producers' access to supermarkets, financed by the International Fund for Agricultural Development (IFAD) and coordinated by CIRAD. This project was conducted from 2007 to 2009 by the MALICA consortium (Markets and Agriculture Linkages for Cities in Asia, www.malica-asia.org). Pilot initiatives were jointly conducted by the research and development departments of the Ministry of Agriculture, IFAD and CIRAD. To date, Superchain has led to the publication of a report and two methodological documents:

- Moustier P., Dao The Anh, Silinthone Sacklokham, 2009. Linking small-scale farmers to supermarkets and other quality chains. Final Superchain report. http://www.malica-asia.org (published in
Vietnamese at the Maison de l'agriculture).

- Moustier P., Dao The Anh, 2009. Guidelines for smallholder access to high quality value chains in Vietnam. A handbook based on the Superchain experience. http://www.malica-asia.org (forthcoming in Vietnamese at the Maison de l'agriculture).Moustier P, Nguyen Thi Tan Loc, Huaiyu Wang, 2009. Guidelines on good trading practices for vegetable farmer organizations. Superchain working paper. http://www.malica-asia. org (forthcoming in Vietnamese at the Maison de l'agriculture).

- The "Making markets work better for the poor" project financed by the Asian Development Bank (ADB) and the UK Department for International Development (DFID). It generated the following papers:

- Figuié M., Moustier P., 2009. Market appeal in an emerging economy:
Supermarkets and poor consumers in Vietnam. In Food Policy, 34 (2): 210-217.

- Moustier P., Phan Thi Giac Tam, Dao The Anh, Vu Trong Binh, Nguyen Thi Tan Loc, 2009. The role of farmer organisations supplying supermarkets with quality food in Vietnam. In Food Policy, 35 (1): 69-78.

- Moustier P., Figuié M., Dao The Anh \& Nguyen Thi Tan Loc, 2009. Are supermarkets poor-friendly? Debates and evidence from Vietnam. A. Lindgreen and M. Hingley (eds), "Controversies in Food and Agricultural Marketing", Gower Publishing, p. 311-327.
42, rue Scheffer

75116 Paris. France

wWW.cirad.fr 